\title{
Is Antitrust Too Complicated for Generalist Judges? The Impact of Economic Complexity \& Judicial Training on Appeals
}

\author{
Michael R. Baye \\ Federal Trade Commission \& Indiana University \\ Joshua D. Wright \\ University of Texas \& George Mason University
}

Preliminary and Incomplete Draft, November 5, 2008. Comments Welcomed.

\begin{abstract}
Modern antitrust litigation sometimes involves complex expert economic and econometric analysis. While this boom in the demand for economic analysis and expert testimony has clearly improved the welfare of economists - and schools offering basic economic training to judges - little is known about the empirical effects of economic complexity or judges' economic training on decision-making in antitrust litigation. We use a unique data set on antitrust litigation in district courts during 1996-2006 to examine whether economic complexity impacts decisions in antitrust cases, and thereby provide a novel test of the frequently asserted hypothesis that antitrust analysis has become too complex for generalist judges. We also examine the impact of one institutional response to economic complexity: basic economic training by judges. We find that decisions involving the evaluation of complex economic evidence are significantly more likely to be appealed, and decisions of judges trained in basic economics are significantly less likely to be appealed than are decisions by their untrained counterparts. Our results are robust to a variety of controls, including the type of case, circuit, and the political party of the judge. Our tentative conclusion, based on a revealed preference argument that views a party's appeal decision as an indication that the district court got the economics wrong, is that there is support for the hypothesis that some antitrust cases are too complicated for generalist judges.
\end{abstract}

Keywords: antitrust, Daubert, complexity, economic training, expert witness JEL Classifications: A2, All, K21, K41, L4

\footnotetext{
- Baye: Bureau of Economics, Federal Trade Commission; Department of Business Economics and Public Policy, Kelley School of Business, Indiana University, Bloomington IN 47405. Email: mbaye@indiana.edu; Wright (Contact author): Visiting Professor, University of Texas School of Law, Austin TX 78705; George Mason University School of Law (on leave). Email: jwrightg@gmu.edu. We thank Joshua Dutill, Spiros Komis, Aubrey Steumpfle, Judd Stone, Jan Rybnicek and Brandy Wagstaff for research assistance and Ronen Avraham, Jonathan Baker, Henry Butler, Malcolm Coate, Frank Cross, Harold Demsetz, Benjamin Klein, Stefanie Lindquist, Kate Litvak, Thomas Hazlett, Geoffrey Manne, Henry Manne, Kimberly Moore, Matthew Sag, Todd Zywicki and the participants at the Stanford and UCLA Law and Economics workshops for valuable comments. The views expressed are our own and do not necessarily represent those of the Federal Trade Commission or any of the individual Commissioners.
} 


\section{Introduction}

Antitrust analysis is becoming increasingly complicated. Modern antitrust litigation and agency practice typically involves judicial evaluation of complex economic and econometric analysis. The "battle of the experts" has become a standard, and critical, battle in the antitrust litigation wars. Mandel (1999) describes the expert witness "boom" in antitrust and a handful of other areas over the past several decades and the growing reliance by judges and regulators on economic consultants to inform decisions. While this boom in demand for expert economic analysis and testimony has clearly improved the welfare of economists, there has been little empirical examination of the effects of economic complexity in antitrust litigation.

There are a number of plausible explanations for the increased reliance on expert economic analysis in antitrust litigation. One explanation is that advances in industrial organization (and economics more generally) have rendered antitrust a more technically

demanding field. A second, not mutually exclusive, explanation is changes in substantive antitrust doctrine. Fifty years ago, antitrust law consisted primarily of per se rules and bright line prohibitions, and thus economic analysis was not required to determine whether business conduct violated the antitrust laws. The success of the law and economics movement over the past 50 years, however, has resulted in a shift towards a modern antitrust landscape favoring a case-by-case, rule of reason approach to evaluating business conduct. Under this modern, "effects-based" approach, judges and juries are 
frequently called upon to determine which business arrangements are anticompetitive, and which are not.

The largely effects-based structure of modern antitrust law invites economic expert testimony in large part because the Sherman Act's broad language delegates to the judicial branch the task of developing a body of "federal common law," including the design of legal standards to identify unreasonable restraints of trade. This task can be daunting for a generalist judge grappling with questions involving merger simulations, demand elasticity, critical loss analysis, the competitive effects of vertical restraints, and evaluating conflicting econometric analyses. Discussing statistical evidence, Judge Richard Posner (1999) argues that "econometrics is such a difficult subject that it is unrealistic to expect the average judge or juror to be able to understand all the criticisms of an econometric study, no matter how skillful the econometrician is in explaining the study to a lay audience." This statement paints a bleak picture for those with hopes of the antitrust enterprise continuing to incorporate modern economic techniques and methods.

The economic complexity of modern antitrust is partly attributable to the success of the law and economics movement. From an historical perspective, economically incoherent decisions are now relatively rare compared to the state of affairs that lead to Bork's (1978) seminal and devastating critique of the paradoxical nature of the antitrust enterprise. The last half century has seen a dramatic increase in the economic sophistication of antitrust analysis in litigation as well as agency practice. Merger 
enforcement decisions are no longer based on the elimination of "small dealers and worthy men," populist considerations, or slavish reliance on industry concentration as a predictor of market performance. Instead, modern merger analysis involves sophisticated predictions of the merger's probable impact on consumer welfare grounded firmly in economic theory and econometrics. Leading antitrust commentators have praised these developments. Describing the FTC's successful challenge of the proposed Staples/ Office Depot merger, which relied on complex econometric testimony showing the merger would result in higher prices to consumers, Judge Posner (2001) announced that "economic analysis of mergers had come of age."

There is now little doubt that complex economic and econometric analyses are standard fare in modern antitrust litigation, but there is a dearth of empirical evidence addressing what impact, if any, this complexity has had on judicial decision-making. An ABA Antitrust Section Economic Evidence Task Force consisting of leading economists, lawyers, academics, and a federal judge undertook a study of the role of economic evidence in federal court. The Task Force Report (Baker and Morse, 2006) reached general consensus "regarding the importance of economics in modern antitrust law and the recognition, therefore, that it is critical that judges and juries understand economic issues and economic testimony in order to reach sound decisions" and that "these problems can seriously affect the adversarial process by skewing judicial outcomes, by leading decision makers to ignore conflicting economic testimony or come to 'wrong' conclusions, and can 
increase litigation costs." An ABA Task Force survey of 42 antitrust economists revealed that only 24 percent believe that judges "usually" understand the economic issues in a case. The ABA Task Force Report and other commentators have suggested a number of possible solutions to the "problem" of economic complexity and expert evidence ranging from increasing use of court appointed experts pursuant to Federal Rule of Civil Procedure 706 (a), expanded use of Daubert to deter unsupported economic testimony, introduction of concurrent evidence procedures, creating specialized courts, and supplying basic economic training to judges (Posner, 1999).

The training of judges, particularly in economics, has become a controversial topic. The appeal of providing judges with basic microeconomic training in antitrust and other areas where the law has adopted an economic approach is obvious. It is difficult to imagine how a judge untrained in economics might evaluate the competitive effects of a defendant's complex pricing scheme solely by relying on precedent, statutory interpretation, casual empiricism, and untrained intuition. Posner (2008) notes the promise of improved judicial performance in antitrust, an area where legalist techniques are particularly unlikely to resolve open questions, in a hypothetical legal system where judges would be "armed with basic economic skills and insights." The ABA Task Force recommends "greater education for judges about antitrust economics, given the limited antitrust and economics expertise that most judges bring with them to the bench when appointed." 
Nonetheless, some have criticized educational programs designed to teach judges economics and other subjects. The George Mason University Law and Economics Center (LEC), the most successful of these programs, has been the focus of much of the criticism at least in some part because it has been the most successful of the judicial training organizations. The LEC began training judges in 1976 and has trained hundreds of federal judges currently on the bench. Teles (2008) notes that by its height in 1990, the LEC Economic Institute for federal judges had trained 40 percent of the federal judiciary, including two Supreme Court Justices and 67 members of the federal courts of appeals. The LEC programs have not been without controversy. Critics have claimed that the programs amount to nothing more than junkets designed to influence judicial decisionmaking, and are a thinly disguised attempt at indoctrinating judges with a particularly conservative, free-market oriented style of economics. Opposition to these programs recently led to proposed legislation that would effectively prohibit privately funded programs for federal judges (Teles, 2008).

This paper represents a first attempt to examine the effects of economic complexity and basic economic training on judicial decisions in antitrust. We find that that economic complexity significantly increases the likelihood that a district court's decision is appealed. This effect is statistically and practically significant, with economically complex decisions 
being appealed about 9 percent more frequently than "simple" cases. ${ }^{1}$ Additionally, we find that the decisions of judges with basic LEC training are appealed in simple cases at significantly lower rates than their untrained counterparts. We find no evidence that basic LEC training has an impact on appeals in economically complex cases, which is consistent with basic economic training being useful for simple antitrust cases but not ones involving complex economic issues. Our results are robust to specifications controlling for the district court judge's political ideology, the type of case, and other controls.

We believe our results shed light on the relationship between economic complexity and the quality of judicial fact-finding, and in particular on the claim that is often made that antitrust analysis has become too complex for generalist judges to evaluate accurately. We argue that the parties - who have typically invested in expert economists and thus are in a strong position to understand the relative strengths and weaknesses of complex economic arguments - are in relatively good position to determine whether the district court got the economics right or wrong in a case. Thus, by revealed preference, the fact that a party is willing to bear the cost of appealing a district judge's opinion is strong evidence that (at least one party thinks) there was an error in the district judge's decision. Thus, we interpret our findings that economic complexity increases the likelihood of an appeal, and that the decisions of judges with basic economic training are appealed at a

\footnotetext{
${ }^{1}$ In this context, "simple" describes only the absence of economic complexity. Like most other forms of civil commercial litigation, antitrust litigation can be quite complex as the result of considerations unrelated to technical economic sophistication.
} 
significantly lower rate than their untrained counterparts, as evidence that supports the view that some antitrust cases are too complex for generalist judges.

Indeed, modern critiques of important antitrust decisions usually amount to a claim that the judge misunderstood the relevant economics or relied on the wrong expert. But while the assumption that the federal judiciary is not equipped to competently evaluate complex economic and econometric evidence in antitrust cases is often made, and also drives many of the proposed reforms designed to improve judicial accuracy, there has been little empirical evaluation of whether such an assumption is appropriate.

One consequence of the increasing economic complexity of modern antitrust is the emergence of institutional responses designed to mitigate its potentially deleterious effects. As discussed, judicial training in basic economics, using specialized courts, or appointing neutral experts have all been proposed as potential strategies to minimize the impact of excessive technical demands on generalist judges. This paper focuses on the first of these solutions: basic economic training for judges. Specifically, we examine whether appeal rates for federal judges receiving economics training from the LEC are different than their "untrained" colleagues on the federal bench. ${ }^{2}$

Section 2 describes our data set. Section 3 discusses methodological issues regarding our approach, as well as some important caveats and limitations of our analysis.

\footnotetext{
${ }^{2}$ There is related literature on the impact of technical complexity on claim construction decisions in patent law finding that the Federal Circuit reverses district court decisions at a relatively high rate and implies poor performance by the district courts. See, e.g. Moore (2001), Chu (2001), see also Wagner (2004). This literature generally does not control for individual judicial characteristics such as technical scientific background, though Moore (2001) finds no difference in reversal rates between Federal Circuit judges with technical backgrounds and those without.
} 
Section 4 presents our empirical results, while Section 5 concludes with a discussion of some potential policy implications of our findings.

\section{Data}

There are four main categories of data. The first category involves information extracted from the judicial opinions. We have attempted to collect every reported decision in which a federal district court judge made a ruling on the merits of a substantive antitrust claim. ${ }^{3}$ Thus far, our sample includes a total of 716 federal district court decisions from 1996-2006. These cases include antitrust litigation originating in federal district court as well as cases where the district court judge sits in review of an earlier administrative ruling by the Federal Trade Commission. A number of decisions involving antitrust issues were excluded from the sample because they did not involve a decision on the merits of a substantive antitrust claim. ${ }^{4}$

Each decision was coded to include information describing the type or types of antitrust claims litigated (e.g. merger, monopolization, price-fixing, Robinson-Patman, or multiple claims), the procedural stage of the decision (e.g., motion to dismiss, summary judgment, and post-trial motion), plaintiff (FTC, DOJ, private party, state attorney

\footnotetext{
${ }^{3}$ We used Westlaw to collect these decisions with the following search term in the district court database (DCT): (antitrust \& ("Sherman Act" "Clayton Act" "Robinson-Patman Act")).

${ }^{4}$ These decisions were most commonly related to venue and class certification issues. It should also be noted that some cases involved multiple decisions. For example, Smith $v$. Jones might involve separate opinions on the same underlying issues at different procedural stages, or alternatively, separate opinions addressing different antitrust claims.
} 
general), the date of decision, and the winner of the underlying motion. Our data also includes an indicator for whether one of the parties appealed the district court's decision.

The second category of data includes the characteristics of the district court judge. In order to be in a position to attempt to disentangle politics from economic training and other factors that might influence appeals, we collected data on the political ideology of the decision-maker as measured by the party of the appointing President. ${ }^{5}$ We also collected data involving court characteristics, including the federal court of appeals to which each district court judge belonged (thus allowing us to control for potential variation among circuits). This is potentially valuable if one believed, for example, that district court judges within the D.C. Circuit are more competent in handling complex antitrust cases litigated by the nearby enforcement agencies. Additionally, data on circuits permits us to control for potential inter-circuit variation including the political composition and economic sophistication of the appellate court and differences in the substantive antitrust law which might influence the appeal rate. We also include data measuring judge's antitrust experience, measured by the number of antitrust opinions authored prior to the decision in our database.

The third category of data involves measures of economic complexity. We constructed a variable designed to capture whether the disposition of the underlying substantive antitrust issue involved analysis of sophisticated economic or econometric evidence. Specifically, we examined the decisions in each case and recorded the number

${ }^{5}$ We also coded age, race, gender and number of years on the bench. 
of times key terms were referenced that one might expect to see in a complex economic case. These terms are summarized in Table 1.

TABLE 1. Summary of Terms Used to Identify Economic Complexity

\begin{tabular}{lcccc}
\multicolumn{1}{c}{ Term } & Mean & $\begin{array}{c}\text { Std. } \\
\text { Dev. }\end{array}$ & Min & Max \\
Professor of Economics & 0.049 & 0.345 & 0 & 5 \\
Econometrics & 0.052 & 0.651 & 0 & 15 \\
Economist & 0.384 & 1.635 & 0 & 26 \\
Econometrician & 0.071 & 0.415 & 0 & 8 \\
Industrial Organization & 0.059 & 0.501 & 0 & 10 \\
Game Theory & 0.003 & 0.053 & 0 & 1 \\
Statistical Evidence & 0.041 & 0.274 & 0 & 4 \\
Statistics & 0.404 & 1.738 & 0 & 29 \\
Regression & 0.158 & 2.048 & 0 & 46 \\
Statistical Significance & 0.010 & 0.134 & 0 & 3 \\
Expert Witness & 0.320 & 1.284 & 0 & 18 \\
Expert Report & 0.464 & 2.200 & 0 & 26 \\
Economic Expert & 0.268 & 1.847 & 0 & 36 \\
Economic Report & 0.029 & 0.573 & 0 & 15
\end{tabular}

We then constructed an aggregate summary statistic of the overall economic complexity of each decision by computing the total number of times these fourteen terms appeared in a given decision. Figure 1 displays the distribution of this measure of economic complexity. In light of the fact that the majority of the decisions were "simple" cases in that none of these fourteen terms were referenced in the decisions, we created an indicator variable that divided cases into two types: hard and simple. Simple cases generated opinions that did not use these terms at all, while a hard case was defined as one in which one or more of the terms in Table 1 were referenced. Our sample includes 220 hard cases and 493 simple cases. 


\section{FIGURE 1: Distribution of Economic Complexity}

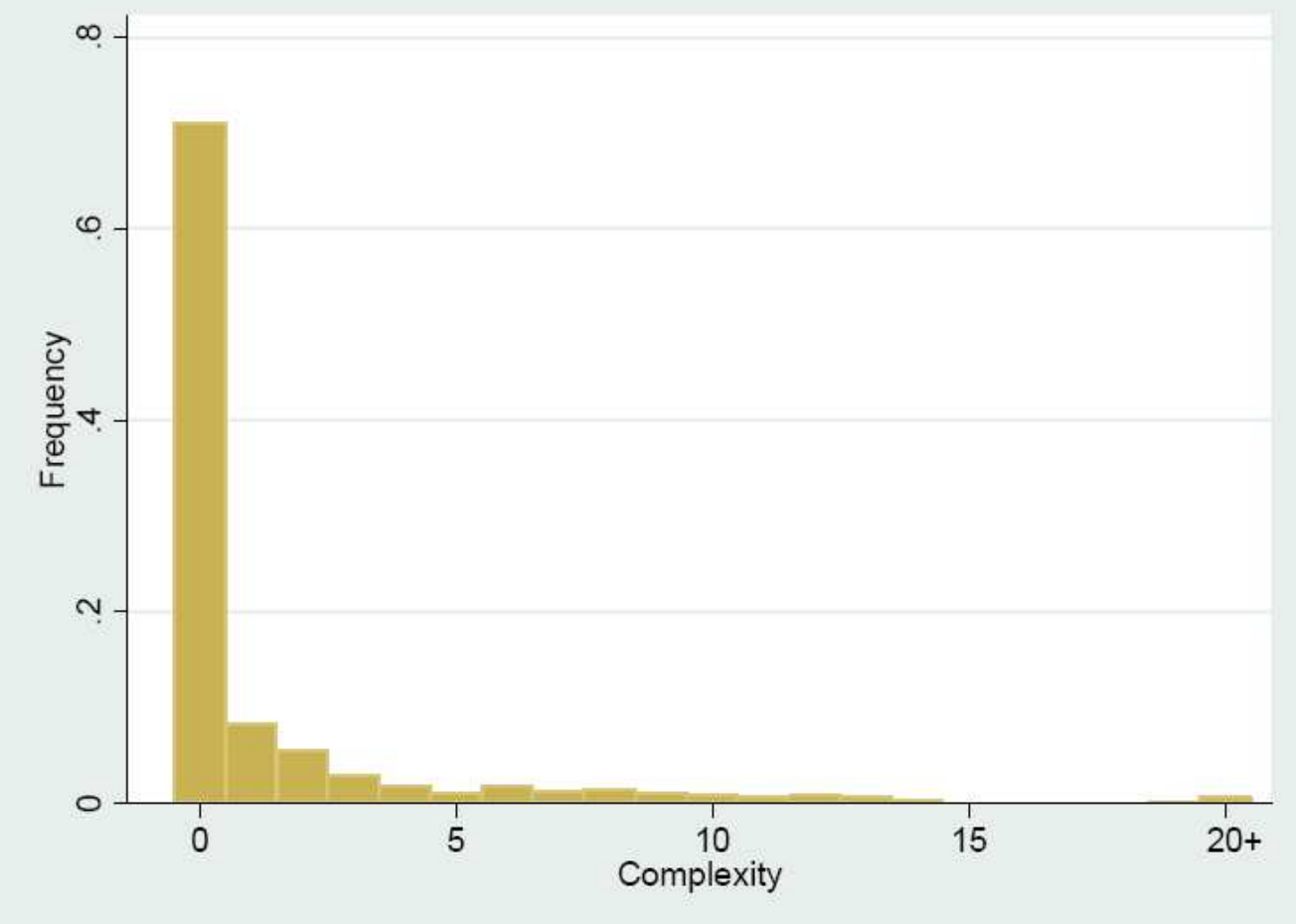

The fourth category of data involves economic training for judges. Using publicly

available sources, we recorded the identity of each federal judge attending basic economic training sessions at the LEC and the date they attended. ${ }^{6}$ A total of 128 judges in our sample attended LEC economics training seminars during the relevant time period, with some attending multiple programs. The purpose of this variable is to measure a judge's ability to analyze economic evidence in an antitrust case. A judge was considered

\footnotetext{
${ }^{6}$ We used a number of data sources to compile this information. The primary source is the searchable database at http://www.tripsforjudges.org/search.asp. The database is the project of the Community Rights Counsel, a small environmental group that has been a vocal critic of the LEC and other judicial education programs, such as the Foundation for Research on Economics and the Environment (FREE) and the Liberty Fund (Adler, 2005). The database compiles judges' financial disclosure forms from 1992-2004. We've supplemented this information with more recently published financial disclosures and records available at the George Mason University Law and Economics Center.
} 
"trained" for the purpose of our analysis only if the judge attended an LEC training session before the date the decision was issued.

LEC training is a proxy for a judge's ability to comprehend basic economic evidence. To the extent one is interested in measuring the effect of more generally acquired economic skills, a more accurate measure of technical competency would be the judge's educational background. For example, one could record whether the judge has an undergraduate or graduate degree in economics, math, or science as a proxy for possessing the technical skills relevant to analyzing complex economic or econometric evidence. While we are currently collecting such data, it is not yet available.

We believe the LEC data are potentially useful in measuring economic expertise for several reasons. First, because one might suspect that the judges who attend basic economic training sessions are the least likely to have any economic sophistication or skills to begin with, ${ }^{7}$ it is more likely that any impact of training on appeals can be attributed to a judge acquiring basic economic skills. Second, LEC training is just one form of judicial economic education. To the extent that many of the proposed institutional reforms, such as more liberal use of court appointed experts, are designed to "train" judges with respect to some relevant technical skill, our results may be probative of the potential impact of those alternative reforms. Finally, and as discussed earlier, the merits of the judicial

\footnotetext{
${ }^{7}$ Programs consisted of a two and a half week course in basic microeconomics taught by instructors including Armen Alchian, Harold Demsetz, Martin Feldstein, Milton Friedman, Paul McAvoy, and Paul Samuelson (Teles, 2008). Charles Goetz, an instructor in LEC training programs, describes the content as "pretty much straight economics ... . the competitive model, capital values, discounting to present value, that sort of thing." (Teles, 2008).
} 
economic training programs (and the LEC in particular) have been the subject of intense debate and proposed legislation on the grounds that the programs are a merely a cover that allows corporate donors to influence judicial decision-making rather than teaching substantive economics. As we shall see, our results suggest that there is an actual "economic training" effect, even controlling the political party of the district court judge and other factors. Thus, these criticisms are misplaced.

\section{$3 \quad$ Methodology and Caveats}

The primary challenge related to this project is identifying a reliable measure of decision quality. Many studies attempting to measure the quality of lower court performance have relied on reversal rates rather than the decision to appeal, presuming that a reversal by the "higher" court warranted the inference that the initial decision was wrong. For a number of reasons, we believe that appeals are a superior measure of the "accuracy" or quality of lower court decision-making in this context. Thus, we estimate the probability of appealing a specific district court decision as a function of economic complexity, the judge's economic training, and a variety of controls.

Our first reason for using appeals to measure the quality of lower court performance derives from a revealed preference argument. That is, the appeal rate is a signal generated by the actual costs incurred by the parties rather than the ex post decision of the appellate court. If the appellate court makes decisions with error, the ex ante decision to appeal can be a more accurate measure of reversibility related to judicial error 
than the ex post appellate decision to reverse. In many antitrust cases, the parties, informed by their economic experts, may well have better information about whether the district court committed (or is sufficiently likely to have committed) "reversible error" than the appellate court will have. While there are reasons for a party to appeal any given district court decision that are unrelated to its quality, ${ }^{8}$ it should generally be the case, ceteris paribus, that observing an appeal signals that at least one party believes that it can convince a higher court that the initial decision contains reversible error. A reduction in the appeal rate is likely to mean that judges issued fewer opinions that left at least one party feeling strongly enough to invest in the opportunity to persuade an appellate court that the district court committed reversible error. It is true that an appeal can also indicate that at least one party wishes to invest in the opportunity to persuade an appellate court that the district committed a legal error, such as applying the wrong standard, unrelated to the type of antitrust fact-finding involving economic analysis that is the subject of our study. However, modern antitrust law is unique in the overlap between legal and economic inquiries, suggesting a large fraction of appeals will be motivated by the view that the district court "got the economics wrong."

\footnotetext{
${ }^{8}$ While a high appeal or reversal rate could indicate a failure of generalist judges to appreciate the technical economic complexity underlying antitrust analysis it might also, for example, merely reflect a period of uncertainty in the law that may decrease over time or a disagreement between district court and appellate judges on the substantive merits (Wagner, 2004).

${ }^{9}$ For example, it is difficult to conceive of an exclusively "legal" challenge to a district court decision in a merger case where the legal standard is whether the merger is likely to "substantially lessen competition," a test that has taken on almost exclusively economic meaning. More generally, Posner (2001) has explained that the subtitle "An Economic Perspective," was dropped from his influential antitrust treatise because "the
} 
Moreover, parties typically invest in hiring economic experts, and are likely to be well-informed about the strengths and weaknesses of complex economics. In contrast, for all of the cases in our sample, judges did not utilize a court appointed expert, and thus were on their own to evaluate the evidence produced through any "battle of the economic experts." In short, there are reasons to believe that the parties (through their experts) are in a better position to evaluate whether a judge missed an important economic point than an appellate judge.

While the appeal rate is an imperfect measure of whether the initial court got the economics "wrong," given our goal of examining the impact of complexity and training on the quality of district court decisions, we believe it is better than merely presuming that appellate courts do not err. There is no evidence that appellate panels are more likely than federal district court judges to possess the technical skills to evaluate complex economic and econometric evidence. Thus, using reversal rates to justify negative inferences about the quality of the district court decision is problematic in this context. Additionally, because the characteristics of the district court judge might influence both the decision to appeal and the conditional probability of a reversal given the decision to appeal, estimating reversal rates runs into an endogeneity problem.

The second reason to prefer appeals over reversals is methodological in terms of better statistics. While appeal rates and reversal rates are inextricably intertwined signals,

other perspectives have largely fallen away," and that there is now "a consensus that guidance must be sought in economics." 
one reason to prefer the appeal rate is simply that it provides a stronger measure of the same underlying concept - possibly reversible error. Assume for example, that an appeal is made only when reversal is a significant possibility, say a $1 / 3$ or greater chance in the appellant's opinion. Assume, too, that appellants are perfectly accurate in their judgments, and that half of all appeals are successful. Under these assumptions, both appeal rate and reversal rate would provide measures of quality, but we would lose half of the signal by using reversal rates. Hence, we would have lower statistical reliability. Our findings our consistent with this analysis in that our reversal rate regressions produce similar, but less reliable, results..$^{10}$

Finally, reversals of district court decisions involve the decisions of multiple decision-makers, each with potentially different political ideologies and economic training. Personal interactions among these decision-makers make it difficult to control for the effects of the characteristics of individual appellate judges (such as party or LEC training) on the appellate court's reversal decision. To the extent that an LEC trained appellate judge might use his or expertise to influences the decisions of his or her untrained colleagues, it is far more difficult to control for judge characteristics using the reversal approach. For these reasons, and other things equal, we view a party's appeal of a district court decision as an indicator of potential judicial error by the district court.

\footnotetext{
${ }^{10}$ For instance, district court opinions authored by LEC trained judges are reversed only $13.6 \%$ of the time while their untrained counterparts' decisions are reversed $23.9 \%$ of the time. Similarly, complex cases in our sample are reversed $28.2 \%$ of the time while simple cases are reversed only $18.6 \%$ of the time. While these results are similar in direction and magnitude to our appeal results reported in Tables 2 and 3, the differences are not statistically significant.
} 
Our analysis is, of course, not without limitations. As discussed earlier, the majority of cases in our sample are economically "simple," and there is not sufficient thickness in the data to separately control for each of the terms in Table 1 . Thus, we have classified a decision as "hard" if it includes one or more of the terms in Table 1 and "simple" if it does not. ${ }^{11}$ Importantly, however, it is possible that decisions including these terms could involve very little sophisticated economic or econometric analysis.

Economically simple cases can be legally challenging, and vice versa. It is also possible that decisions are economically complex despite the absence of any of these terms. An informal review of our sample suggests that the "hard" cases consistently involve at least some evaluation of expert economic evidence, "simple" cases do not, and false negatives (e.g. cases coded as "simple" but involving evaluation of expert economic evidence) are more common than false positives ("hard" cases that do not involve any evaluation of economic or econometric evidence). Nonetheless, we acknowledge that our measure of economic complexity is merely a proxy for an admittedly nebulous concept.

Another limitation of our analysis is that we do not have data to control for some other potentially important predictors of the appeal rate. The most important of these omitted variables is the stakes of the underlying litigation which is likely to be a significant predictor of the appeal rate. Two of our control variables can be interpreted as controlling

\footnotetext{
11 We also ran other specifications that treated complexity as a continuous variable. Our finding that complexity increases the probability of appeals and that LEC training reduces appeals is robust to these alternative specifications as well as specifications using decision length (number of words) as our measure of complexity.
} 
for litigation stakes. First, our control for type of case distinguishes merger cases from price-fixing or monopolization allegations and is a reasonable proxy for stakes in the antitrust litigation context. ${ }^{12}$ Second, one might interpret our complexity measure as capturing the presence of an expert report and thus correlated with litigation stakes. To the extent that our measure of complexity and litigation stakes are highly correlated, one might have less confidence that our complexity results are solely attributable to the technical economic complexity of the decision rather than both complexity and stakes effects. However, our basic economic training results are robust to specifications including both our measure of complexity and controls for the type of case, which is also correlated with litigation stakes.

We do not have access to some other important predictors of the appeal rate. For example, we do not have data on the quality of the lawyers on either or both sides. District court judges might also rely on unobserved methods, unrelated to economic training or education, to signal their grasp of the economic issues to the parties. This would reduce the likelihood of appeal for any given level of economic training or complexity. In addition, district court judges' abilities to evaluate complex economic evidence might improve with repeated exposure to antitrust cases over time, and there could be judge-specific effects. Unfortunately, the data are not rich enough to permit us to control for all of these possibilities.

\footnotetext{
${ }_{12}$ Bizjak and Coles (1995) find litigation involving horizontal conspiracy allegations to be associated with larger negative wealth effects than vertical allegations involving monopolization, and that Clayton Act merger litigation has larger effects than other forms of litigation in stock market event studies.
} 
Finally, our sample of cases is not random. Since our sample consists of only litigated cases, it is a well known result that these cases are likely to include cases that are "close calls" (Priest and Klein, 1984). For our purposes, this sample selection does not impact our ultimate research question: how well do generalist district court judges evaluate economic evidence in modern antitrust litigation? In other words, we are interested in how well judges evaluate these close calls, not the substantive merits of the underlying allegations. To the extent that the mix of litigated cases changes over time in important ways that might correlate with decision quality or complexity, we include controls such as a time trend and type of case.

\section{Economic Complexity, Judicial Training and Appeal Rates}

\subsection{Complexity, Economics Training and Appeal Rates}

We begin with some simple comparisons of means to explore differences in the appeal rates in hard and simple decisions, as well decisions by LEC-trained and untrained judges. Table 2 reports results. Economically hard cases in our sample are 23.8 percent more likely to be appealed than simple cases. The difference is statistically significant at the 1 percent level, and in practical terms, quite large. In 50 percent of cases involving evaluation of complex economic or econometric evidence, the district court decision is appealed. In contrast, only 26.2 percent of the decisions in economically simple cases are appealed. With respect to basic economic training, district court decisions authored by judges who have attended an LEC training session are 12.4 percent less likely to be 
appealed. This difference is also both statistically (at the 1 percent level) and practically significant. District court judges who have attended LEC basic economic training programs prior to authoring an antitrust decision have that opinion appealed only 22.7 percent of the time.

TABLE 2

Mean Testing: Economic Complexity and LEC Training Two-sample t-test with equal variances

\begin{tabular}{cccc}
\hline Variable & N & Mean & Std. Err \\
\hline \hline Hard Appeal & 220 & 0.500 & 0.034 \\
Simple Appeal & 493 & 0.262 & 0.020 \\
Combined & 713 & 0.335 & 0.018 \\
Difference & & 0.238 & 0.037 \\
T-Statistic & $\mathbf{6 . 3 9}$ & & \\
& & & \\
LEC Appeal & 97 & 0.227 & 0.043 \\
No LEC Appeal & 618 & 0.351 & 0.019 \\
Combined & 715 & 0.334 & 0.472 \\
Difference & & -0.124 & \\
T-Statistic & $\mathbf{2 . 4 2}$ & & \\
\hline
\end{tabular}

These means tests provide preliminary evidence that both complexity and judicial economic training are important predictors of appeal rates in antitrust cases. However, it is possible that the correlations between complexity, LEC training and appeals may be the result of omitted variable bias confounding their true impact. In the remainder of the paper, we use a probit regression framework to control for possible influences and isolate the impact of economic complexity and judicial training on antitrust appeals. 


\subsection{Probit Regressions}

In each of our regressions the dependent variable is appeal, an indicator set equal to 1 if the district court decision is appealed and zero otherwise. Our primary independent variable of interest is hard, a dummy variable taking the value of one when the district court opinion included at least one of the terms in Table 1 (indicating the presence of complex economic or econometric evidence) and zero otherwise. A second independent variable of interest is $L E C$, a dummy variable that equals one if the district court judge issuing an antitrust opinion attended an LEC training course in basic economics prior to the decision, and zero otherwise. To further explore the impact of judicial training on appeals, we generated two interaction terms: $h a r d \_L E C$ and simple_LEC. The interaction terms allow us to isolate the marginal impact of LEC training on appeals in "hard" cases involving economic and econometric evidence as well as "simple" cases where basic economic training is more likely to have a greater marginal effect.

To explore the effect of these variables on the appeal rate, we estimated a series of probit regressions that include the above key variables along with a set of controls that are potentially predictive of the appeal rate. These controls include a time trend, dummy variables indicating the circuit in which the decision was litigated, the type of antitrust 
claim involved, as well as the political party of the president appointing the deciding judge. ${ }^{13}$ Table 3 reports marginal effects along with robust standard errors.

Specification (1) is our baseline model, which is similar to the means comparisons in Table 2 except that it simultaneously controls for both economic complexity and LEC training. The results are similar in magnitude and significance to the mean tests reported

Table 3: Probit Regressions Reporting Marginal Effect on Appeal Rate Marginal Effect with Robust Standard Errors in Parentheses

\begin{tabular}{lccccc}
\hline & $(\mathbf{1})$ & $\mathbf{( 2 )}$ & $\mathbf{( 3 )}$ & $\mathbf{( 4 )}$ & $\mathbf{( 5 )}$ \\
\hline \hline HARD & $0.2322^{* * *}$ & $.0821^{*}$ & $.0772^{*}$ & $.0902^{* *}$ & $.0867^{*}$ \\
& $(0.0394)$ & $(.0447)$ & $(.0448)$ & $(.0473)$ & $(.0476)$ \\
LEC & $-.1052^{* *}$ & & & & \\
HARD_LEC & $(.0483)$ & & & & \\
& & .0988 & .1199 & .1038 & .0997 \\
SIMPLE_LEC & & $(.1131)$ & $(.1155)$ & $(.1124)$ & $(.1156)$ \\
& & $-.0931^{*}$ & $-0.0897^{*}$ & $-.0920^{*}$ & $-.0934^{*}$ \\
PARTY & & $(.0506)$ & $(.0507)$ & $(.0503)$ & $(.0504)$ \\
& & .0079 & .0057 & .0093 & .0001 \\
YEAR & & $(.0354)$ & $(.0354)$ & $(.0354)$ & $(.0357)$ \\
& & & $-.0080^{* *}$ & $-.0080^{*}$ & $-.0086^{* *}$ \\
TYPE OF CASE & No & No & $(.0038)$ & $(.0043)$ & $(.0043)$ \\
& & & & No & Yes \\
CIRCUIT & No & No & No & No & Yes \\
& & & & & \\
\hline *** $\mathrm{p}<.01$ & & & & & \\
** $\mathrm{p}<.05$ & & & & &
\end{tabular}

\footnotetext{
${ }^{13}$ We also controlled for the procedural stage of the district court decision and whether the plaintiff was a government agency, private party, or state attorney general. Results in these specifications are similar to those reported here and are available from the authors upon request.
} 
in Table 2, with complex cases being appealed 23.22 percent more often than simple cases and LEC training reducing the probability of appeal by approximately 10 percent. This is consistent with our expectation that economically complex cases are more likely to result in larger zones of reasonable factual disagreement on substantive issues and divergent expectations with respect to the likelihood of success on appeal. A more cynical interpretation of this finding would be that more complex cases raise more difficult factfinding determinations and therefore, more opportunities to commit reversible error in the eyes of the reviewing court.

Specification (2) uses interaction terms to determine whether LEC training has a differential impact on appeals rates in hard and simple cases, and adds a control for the political affiliation of the judge. ${ }^{14}$ As before, decisions involving complex economics or econometrics are more likely to be appealed than simple cases: Hard cases are 8.21 percent more likely to be appealed than simple cases, and the effect is statistically significant at the 10 percent level. Interestingly, basic LEC training does not have a statistically significant effect on complex cases (the coefficient of HARD_LEC is statistically insignificant at conventional significance levels), but reduces the appeals rate in simple cases by a statistically significant 9.31 percent (the coefficient of SIMPLE_LEC). This consistent with what one might expect: Basic economic training is not enough to help judges get the economics right in complex cases, but has a high marginal return in simple cases. Notice

\footnotetext{
${ }^{14}$ Specifications including LEC, HARD and one interaction term (HARD_LEC) generated similar results.
} 
that party affiliation is not economically or statistically significant, which suggests that LEC training and economic complexity - not a spurious correlation between political ideology and the propensity of a judge to opt for LEC training - are the primary determinants of decisions to appeal a decision.

Specifications (3), (4) and (5) in Table 3 reveal that these results are robust to, respectively, the addition of a simple time trend, dummy variables to control for the type of case (merger, monopolization, price discrimination, or price-fixing), and dummy variables to control for the circuit in which the case was litigated. In all specifications, hard cases are 8 to 9 percent more likely to be appealed than simple cases, and arming judges with basic economic skills reduces the appeal rate in simple cases by about 9 percent. Generally speaking, the type of claim, procedural stage, the circuit court of appeals within which the case is filed, whether the plaintiff is a government agency, and the political party of the district court judge are not significant predictors of appeals. ${ }^{15}$

One potential concern with the results in Table 3 is that judges receiving LEC training are not randomly assigned. For example, LEC training might be correlated with another characteristic impacting the appeal rate. One such selection hypothesis is that judges attending LEC training programs may be more politically conservative or otherwise more pre-disposed to economics and market oriented thinking than their

\footnotetext{
${ }^{15}$ Moore (2001) also finds that the political party of the appointing president does not predict reversal rates in district court patent claim construction cases. But see Sag et al (2008) who find that political ideology is a significant predictor of outcomes in Supreme Court intellectual property cases, including the subset of cases involving the intersection of intellectual property and antitrust.
} 
untrained counterparts. If that were so, LEC attendance might be capturing some preexisting differences in economic sophistication or orientation of the judges rather than the effect of basic LEC training. While we have attempted to control for this by including PARTY in specifications (2) through (5) of Table 3, we also examined the possibility that LEC training impacts Republican and Democrat judges differently based on these underlying and unobserved differences by estimating variants of the model that allow differential effects of LEC training on republican and democratic judges. The results are similar to those reported in Table 3. For instance, in a specification analogous to that in specification (1), economic complexity increases the likelihood of appeal by 23 percent (significant at the 1 percent level), and the impact of LEC training for both Republican and Democrat judges is similar in both magnitude and direction: -10.6 percent for Republican judges and -10.1 percent for Democrats. ${ }^{16}$ Thus, it does not appear that the reduction in appeals associated with LEC training is an artifact of the ideology of those opting to take such training in the first place.

\section{$5 \quad$ Conclusions}

Modern antitrust litigation involves more economic sophistication than it did even 20 or 30 years ago. The evolution of antitrust into an economically coherent body of doctrine from its notoriously incoherent and non-economic origins has been nearly universally heralded as a favorable development. As economists, we certainly consider

\footnotetext{
${ }^{16}$ Neither interaction term is significant at the 10 percent level, with p-values of .106 and .181, respectively. Similarly, LEC training is not a significant predictor of the defendant win rate in our sample. These results are available from authors upon request.
} 
the evolution of antitrust doctrine over the past 30 years to be a positive development for consumers. Our inquiry examined whether the incorporation of economic sophistication into modern antitrust analysis may have reached the point of diminishing marginal returns. While commentators have discussed the challenges facing generalist judges charged with the task of sifting through competing expert economic evidence in complex antitrust cases, and their failures in individual cases, we present the first empirical evidence of the relationship between technical economic complexity and antitrust litigation. We also are able to examine whether basic economic training for judges mitigates the negative impact of this form of complexity on judicial decision-making.

The evidence here suggests that economic complexity and training influence the appeal rate in opposite directions. Economic complexity significantly increases the probability of appeal, while judicial training reduces it. The effects are of similar magnitude. More specifically, our first finding is that there is a statistically and practically significant positive relationship between economic complexity and appeals. Decisions involving some evaluation of economic or econometric evidence are appealed approximately 9 percent more frequently than cases demanding less economic skill.

That a decision was appealed suggests that at least one party is willing make a costly investment for the opportunity to persuade an appellate court that the district court judge erred. This should be more likely in cases involving complex economic evidence because there are likely to be reasonable fact-finding dispute and thus, more room to 
persuade an appellate court that a reversible error has been committed by the lower court. This result provides some empirical support for the claim that economic complexity is having an important impact on antitrust litigation. Our finding also provides some support for the oft-raised claim that the ever increasing levels of economic sophistication and complexity in modern antitrust litigation are now generating negative marginal returns. While one may reasonably dispute whether this relationship between complexity and appeals is strong evidence of a divergence between the technical demands of contemporary antitrust analysis and the technical economic skills of the federal bench, it is clear that economic complexity is an important part of the modern antitrust litigation landscape.

Our second finding is that the decisions of judges who attended LEC programs to learn basic economic skills are appealed at the same rate as their untrained counterparts in complex cases, but 9 percent less often in cases that do not involve the evaluation of sophisticated economic or econometric evidence. This effect of economic training has interesting implications for understanding the impact of economic complexity in antitrust litigation. One interpretation of these findings is that while adding basic economic skills does not enhance the accuracy of judicial fact-finding in technically complex cases, these skills do allow trained judges to identify and "correctly" decide simple cases. This interpretation is consistent with the "entry level" content of LEC programs. Exposure to basic economics is not likely to prepare a district court judge to evaluate the type of 
complex econometric testimony seen in many modern antitrust cases. However, these skills are more likely to enable a district court judge to identify and correctly decide simple antitrust claims not requiring sophisticated economic analysis.

Judicial economic training appears to be demonstrating both its promise and limits. On the one hand, the reduced appeal rate in simple cases supports the claim that basic economic training improves judicial decision-making. The primary benefit of basic economic training is that judges are able to reach more accurate decisions in simple cases, at least in the sense that the parties are less willing to appeal. Further, the improvement comes in a form that critics of judicial education programs would not predict. Rather than influencing judicial-decision making in a manner that is consistent with political ideology (for example, LEC training resulting in a higher defendant win rate), LEC training appears to have no impact on which party ultimately prevails. To the contrary, the impact of training is similar in magnitude and direction regardless of the political party of the deciding judge.

However, the results also demonstrate that economic training alone is not likely to improve outcomes in the increasing number of complex cases. Improving accuracy in complex antitrust cases involving significant amounts of economic and econometric evidence might require more alternative strategies, such as more liberal use of court appointed experts, or perhaps more drastic measures such as creating specialized antitrust 
courts. We do not take a position on whether any of these alternative measures would be desirable.

In future research, we will extend our analysis to include alternative measures of economic education, such as the undergraduate and graduate educational background of the judge, to empirically test whether this alternative form of economic education impacts decision-making differently than LEC training. We will also include decisions resulting from adjudication in front of Federal Trade Commissioners to examine whether the institutional expertise at the antitrust agencies, which have staffs of professional antitrust economists at their disposal, results in increased competency or enhanced accuracy when facing the challenge of technical economic complexity. 


\section{REFERENCES}

Adler, Jonathan H. (2005), Junkets for Judges, National Review Online (June 23, available at: http://www.nationalreview.com/adler/adler200506230755.asp)

Baker, Jonathan B. and Morse, M. Howard (2006), Final Report of the American Bar Association Antitrust Division Economic Evidence Task Force (available at: http://www.abanet.org/antitrust/at-reports/01-c-ii.pdf).

Bizjak, John M. and Coles, Jeffrey L., The Effect of Private Antitrust Litigation on the StockMarket Evaluation of the Firm, American Economic Review, Vol. 85, No. 3, pp. 436-61.

Bork, Robert (1978), The Antitrust Paradox (Basic Books, Inc.).

Chu, Christian A., (2001), Empirical Analysis of the Federal Circuit's Claim Construction Trends, Berkeley Technology Law Journal, Vol. 16, page 1075.

Mandel, Michael J., Going for the Gold: Economists as Expert Witnesses, The Journal of Economic Perspectives, Vol. 13, No. 2 (Spring, 1999), pp. 113-120

Moore, Kimberly A. (2001), Are District Court Judges Equipped to Resolve Patent Cases?, Harvard Journal of Law \& Technology, Vol. 15, page 1.

Posner, Richard A. (1999), The Law and Economics of the Economic Expert Witness, The Journal of Economics Perspectives, Vol. 13, No. 2 (Spring, 1999), pp. 91-99

Posner, Richard A. (2001), Antitrust Law (2 ${ }^{\text {nd }}$ Edition, University of Chicago Press).

Posner, Richard A. (2008), How Judges Think (Harvard University Press).

George Priest \& Benjamin Klein (1984), The Selection of Disputes for Litigation, $13 \mathrm{~J}$. L. Stud. 1.

Sag, Mathew J., Jacobi, Tonja and Maxim Sytch (2008), Ideology and Exceptionalism in Intellectual Property: An Empirical Study, California Law Review, forthcoming.

Teles, Steven M. (2008), The Rise of the Conservative Legal Movement (Princeton University Press).

Wagner, Polk and Petherbridge, L. (2004), Is the Federal Circuit Succeeding? An Empirical Assessment of Judicial Performance, University of Pennsylvania Law Review, Vol. 152, page 1105. 